\title{
НАКАЗАНИЯ, СВЯЗАННЫЕ С ТРУДОВЫМ ВОЗДЕЙСТВИЕМ, В АНГЛИИ И ФРАНЦИИ
}

Аннотаиия: Настоящая статья представляет собой комплексное, сравнительно - правовое исследование мер принудительного трудового воздействия на осужденных, отбывающих наказания, не связанные с изоляцией от общества. На примере Англии и Франции - представителей англо-саксонской и романо-германской правовых систем отмечается тенденция гуманизации применяемых уголовных наказаний. Принадлежность к разнылм правовым семьям предопределяет особенности назначения и исполнения альтернативных лишению свободы наказаний, связанных с обязательным трудом, что позволяет выделить самостоятельнье модели уголовно-правового воздействия. При этом близкие по содержанию меры могут быть восприняты одинаково в разных странах, что обусловлено глобализацией уголовно-правовой политики. В процессе проведения исследования автором примененьл такие методы, как анализ, синтез, метод аналогии, компаративистский и исторический методы. Статья содержит авторский перевод законодательных источников Англии и Франции, их сравнительно - правовой анализ. Отмечается практическая и теоретическая цеенность зарубежного опьтта для оптимизации системы наказаний в России. Востребованность альтернативных наказаний, сопряженных с трудовым воздействием на осужденных, отвечает основным направлениям уголовной и уголовно - исполнительной политики современных государств.

Abstract: This article provides a complex comparative legal study of the measures of forced labor correction of convicts serving punishments without isolation from the society. Taking examples of England and France (representing Anglo-Saxon and Roman-German legal system) the author shows the tendency for the humanization of the applied criminal punishments. Since these two states belong to different legal families, there are some specificities regarding assignment and execution of alternative punishments (to imprisonment), regarding correctional labor, allowing to single out independent models of criminal law influence. At the same time similar measures may be accepted similarly in different states, which is due to the globalization of the criminal legal policy. In the process of studies the author applied various methods, such as analysis, synthesis, analogy, comparative and legal methods. The article contains references to English and French legislative sources translated by the author, as well as their comparative legal analysis. The author notes practical and theoretical value of foreign experience for the optimization of the system of punishments in Russia. The demand for the alternative punishments involving correctional labor corresponds to the main directions of criminal and penal policies of the modern states.

Ключевые слова: Гуманизация, альтернативнье наказания, трудовое воздействие, обязательные работы, наказания зарубежных стран, пробация, пенитенциарная система, зарубежное законодательство, исполнение наказаний, глобализациия.

Keywords: Humanization, alternative punishments, correctional labor, obligatory labor, punishments in foreign states, probation, penitentiary system, foreign legislation, execution of punishments, globalization.

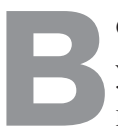

остребованность группы альтернативных уголовных наказаний, связанных с трудовым воздействием на осужденных, в различных правовых системах обусловлена изменением основных направлений уголовной и уголовно-исполнительной политики, новым подходом к пониманию целей назначения уголовных наказаний. Во многих странах целями уголовного наказания стали официально признаваться исправление осужденного, предупреждение совершения новых преступлений и возмещение вреда, причиненного потерпевшему, обществу и государству (community payback) $^{1}$, что сопряжено с гуманизацией и либерализацией уголовных наказаний. Ориентация государств на соблюдение Всеобщей Декларации прав человека, Европейской Конвенции о защите

\footnotetext{
${ }^{1}$ См., например: Criminal Justice Act 2003 http://sentencingcouncil. judiciary.gov.uk/docs/web_new_sentences_guideline1.pdf
} 
прав и свобод человека и гражданина, Европейских пенитенциарных правил и иных международноправовых актов выявила необходимость применения новых альтернативных лишению свободы наказаний, в том числе, связанных с трудовым воздействием на осужденных. По мнению Джона Петерсилла, иной предпосылкой к развитию альтернативных наказаний, связанных с трудовым воздействием, стали перенаселенность тюрем и потребность зарубежных стран в снижении уровня финансирования уголовно-исполнительной системы².

В современной России также предпринимаются активные попытки гуманизации наказания, ведутся поиски внетюремных видов наказания и совершенствования альтернативных лишению свободы средств воздействия на лиц, совершивших преступления. В этой связи изучается зарубежный опыт, рассматривается вопрос о возможности его использования для оптимизации системы наказаний в России (Д.Е. Баталин, И.В. Дворянсков, В.А. Зайченко, В.В. Сергеева и др.) ${ }^{3}$.

К причинам внедрения альтернативных видов наказания в России И.В. Дворянсков относит низкую эффективность лишения свободы, антигуманный характер данного вида наказания, а также экономическую обоснованность возникновения альтернатив лишению свободы ${ }^{4}$.

Альтернативные наказания, связанные с трудовым воздействием, противоречиво характеризуются ученым сообществом. С одной стороны, отмечается приверженность государств к либеральной идее, а именно стремление помочь осужденному исправиться без ограничения его свободы. С другой стороны, поскольку назначение альтернативного наказания сопряжено с принуждением осужденного к неоплачиваемому труду, такое наказание соотносится с понятием «принудительный труд», использованным в Конвенции о

\footnotetext{
${ }^{2}$ Joan Petersilla Probation in the USA

http://www.appa-net.org/eweb/Resources/PPPSW_2013/docs/sp98pers30.pdf

${ }^{3}$ См., например: Дворянсков И. В., Сергеева В.В., Баталин Д. Е. Применение альтернативных видов наказания в Западной Европе, США и России. Центр содействия реформе уголовного правосудия. - М., 2003. С. 18; Зайченко В. А. Альтернативные лишению свободы наказания как средство оптимизации системы уголовных наказаний в США: Автореф. дис... канд. юрид. наук. - Самара, 2005. C.10.

http://www.dissercat.com/search?keys=\%D0\%B7\%D0\%B0\%D0\%B9 $\% \mathrm{D} 1 \% 87 \% \mathrm{D} 0 \% \mathrm{~B} 5 \% \mathrm{D} 0 \% \mathrm{BD} \% \mathrm{D} 0 \% \mathrm{BA} \% \mathrm{D} 0 \% \mathrm{BE} \#$ ixzz2xgMJaCOY

${ }^{4}$ Дворянсков И. В. Эффективность альтернативных наказаний. M., 2005. C. 19.
}

рабстве от 25.09.1926 г. ${ }^{5}$ и п признается нарушающим естественные права человека. Правовая природа таких наказаний тоже определяется по-разному.

Зарубежные страны, закрепившие в своем законодательстве возможность осуществления бесплатных работ на пользу государства и общества либо предусматривают их как самостоятельный вид уголовного наказания с включением в санкции статей уголовных законов, и, одновременно, включают как элемент в содержание пробации и условного осуждения (Франция), либо не выделяют самостоятельный вид наказания, а предусматривают в качестве составного элемента другого наказания - приговора в интересах общества (community order), исполняемого службой пробации (Англия). При этом, меры принуждения, сопряженные с принудительным трудом, именуются по-разному: в Англии закреплено понятие «бесплатные работы» (unpaid work) ${ }^{6}$, во Франции - работы в интересах общества» (un travail d'intérêt general) 7 .

Неоднозначно определяемый статус бесплатных работ (работ в интересах общества) позволяет говорить и о многообразии форм их исполнения. В законодательстве Англии в силу специфики англо-американской правовой системы не существует единого кодифицированного законодательного акта, регулирующего сферу назначения и исполнения уголовных наказаний.

Приговор в интересах общества (community order) с альтернативой лишению свободы, урегулирован множеством одновременно действующих нормативноправовых актов. Например, в соответствии с Актом об уголовном правосудии иммиграции 2008 года (Criminal Justice and Immigration Act) бесплатные работы могут применяться как к совершеннолетним, так и несовершеннолетним лицам 8 : в отношении совершеннолетних - вынесение приговора в интересах общества (community order), в отношении несовершеннолетних - вынесение реабилитирующего приговора (уouth rehabilitation order). Применение данных видов наказаний исключается, если конкретный вид наказания за совер-

\footnotetext{
${ }^{5}$ Конвенция о рабстве 1926 г. http://www.un.org/ru/documents/decl_conv/conventions/ convention_slavery.shtml

${ }^{6}$ Criminal Justice Act 2003 http://sentencingcouncil.judiciary.gov.uk/ docs/web_new_sentences_guideline1.pdf

${ }^{7}$ УК Франции Code pénal http://www.legifrance.gouv.fr/affichCode. do;jsessionid=0DB32EF259C2F56294C051C8DB0A9B9D.tpdjo04v 3?idSectionTA $=$ LEGISCTA000006181727\&cidTexte $=$ LEGITEXT0 00006070719\&dateTexte $=20100907$

${ }^{8}$ Criminal Justice and Immigration Act 2008 http://www.legislation. gov.uk/ukpga/2008/4/contents
} 
DOI: 10.7256/1811-9018.2014.10.12952

При цитировании этой статьи сноска на dоі обязательна

\section{Право и политика $10(178) \cdot 2014$}

шенное преступление установлен законом, либо если преступление связано с незаконным применением огнестрельного оружия, либо при рецидиве преступлений, либо если за преступление предусмотрено пожизненное лишение свободы. Вместе с тем, приговор в интересах общества может быть назначен вместо штрафа при указании судом на соответствие обстоятельств совершения преступления, степени общественной опасности выбранному наказанию. Вынесение приговора в интересах общества допускается, если подсудимый достиг 18 лет, или в возрасте 16 лет совершил три преступления, за каждое из которых был осужден к штрафу.

При назначении приговора в интересах общества суд учитывает степень общественной опасности деяния, природу совершенного преступления, особенности личности виновного, время, прошедшее с момента последнего преступления и действует в соответствии с принципами соразмерности (proportionality) и применимости (suitability). В качестве целей наказания указываются необходимость возмещения причиненного вреда не только государству (community payback), но и потерпевшему (restorative justice), также исправление лица, помощь в реабилитации и возвращении лица к нормальной жизни в обществе.

Приговор в интересах общества закрепляет индивидуальный набор обязанностей, возлагаемых на осужденного. Выделяются 12 видов возможных обязанностей, помимо выполнения бесплатной работы, включаемых в приговор суда, а именно: комендантский час на срок до 12 часов в день с использованием электронного мониторинга (curfew requirement), запрет посещения отдельных общественных мест с использованием системы электронного мониторинга (exclusion requirement), обязанность развивать определенные профессиональные навыки (activity requirement) 9 , обязанность посещать психолога (mental health treatment), лечение от наркотической зависимости (drug rehabilitation), лечение алкоголизма (alcohol treatment), надзорное требование (supervision requirement), посещение центра для лиц до 25 лет (attendance centre requirement). К видам выполняемых бесплатных работ относятся, например, благоустройство парковых и лесных зон, сбор мусора, сведение граффити, украшение улиц перед государственными праздниками, строительство и обслуживание.

Общественный приговор назначается в днях, неделях, месяцах, а бесплатные работы как его составной

\footnotetext{
${ }^{9}$ Может включать содействие усвоению и развитию определенных профессиональных навыков, трудоустройству, получению образования, часто в целях возмещения вреда потерпевшему.
}

элемент исчисляются в часах (минимум - 40 часов, максимум - 300 часов). Весь срок бесплатных работ должен быть выполнен в течение 12 месяцев с соблюдением режима, согласованного с ответственным служащим. Комбинации ограничений, включаемые в общественный и реабилитирующий приговоры, составляют соответствующие уровни предъявляемых обязанностей, устанавливаемые приговором суда. При этом новое преступление не является основанием для повышения требований. При назначении приговора в интересах общества и реабилитирующего приговора учитывается возможность совмещения нескольких видов ограничений и устанавливается предельный срок (не более 3 лет), в течение которого все условия приговоров должны быть выполнены.

Контроль за соблюдением требований может производиться с помощью системы электронного мониторинга. Если лицо нарушает условия приговора в интересах общества, суд имеет право либо увеличить размер предъявляемых требований в рамках данной альтернативы лишению свободы, либо заменить лишением свободы. Суд обязан учитывать возможность лица выполнить новое наказание ${ }^{10}$.

Исполнение наказания производится в несколько стадий. Сначала осужденный проходит проверку в службе пробации (probation service) для подтверждения опасности или безопасности лица для общества. Если лицо не представляет опасности для общества, ему разъясняется порядок и условия исполнения наказания и последствия их нарушения. Каждый осужденный закрепляется за определенным служащим системы пробации (responsible officer), ответственным за исполнение назначенного наказания. Взаимодействие проходит в рамках бесед, определения индивидуального плана бесплатных работ с учетом трудоустройства лица и содержания приказа. Выполнение бесплатных работ производится по месту нахождения соответствующего организационного центра. Предусматривается обязанность осужденного носить отличительный жилет оранжевого цвета. Работы выполняются лицом в зависимости от трудоустройства не менее 6 часов в неделю, с обязанностью закончить выполнение бесплатных работ в течение 1 года. Если у осужденного есть постоянное место работы, то бесплатные работы назначаются сверхурочно или в выходные дни.

Исполнение данной альтернативы лишению свободы осуществляется разветвленной сетью специализи-

\footnotetext{
${ }^{10}$ Criminal Justice Act 2003 http://sentencingcouncil.judiciary.gov.uk/ docs/web_new_sentences_guideline1.pdf
} 
рованных служб, подчиненных Министерству юстиции в Соединенном Королевстве (Ministry of Justice). National Offender Management Service (Национальная Служба Управления по работе с осужденными, NOMS) была создана в 2008 году с целью координации деятельности в области исполнения наказаний ${ }^{11}$. В рамках организации выделены отделы публичных и частных тюрем, система пробации (probation service) и контрактных служб. NOMS представляет собой иерархичную систему служб пробации на местах на территории Англии и Уэльса.

В Англии реабилитирующий приговор в отношении несовершеннолетних (до 18 лет) основывается на Актах: о правомочиях уголовных судов (Powers of Criminal Courts Act 2000) ${ }^{12}$, об уголовном правосудии (Criminal Justice Act 2003), о несовершеннолетних (Children Act 2001) ${ }^{13}$, об уголовном правосудии и иммиграции (Criminal Justice and Immigration Act 2008). Дела в отношении несовершеннолетних (кроме убийств) подсудны отдельным судам (senior courts), и в обязанность магистратских судов (для совершеннолетних) входит перевод данной категории дел по подсудности и освобождение обвиняемого на период до назначения нового судебного заседания. В круг ограничений, включаемых в реабилитирующий приговор, входят обязанности, аналогичные установленным для совершеннолетних.

Ограничения, существующие для назначения приговора в интересах общества, распространяются и на назначение реабилитирующего приговора. Реабилитирующий приговор может быть вынесен, если подсудимому исполнилось 16 лет или, если за ранее совершенные в возрасте 16 лет три преступления подсудимый трижды был осужден к штрафу.

Бесплатные работы выполняются в свободное от учебы время, под контролем служащего системы исполнения наказания (Youth Justice Officer) без использования специальных маркировочных жилетов оранжевого цвета для предотвращения осуждения лица общественностью. Каждые три месяца осужденный встречается со служащим в целях наблюдения за исполнением приговора. Несоблюдение условий приговора влечет продление срока исполнения или назначение судом иного вида наказания.

\footnotetext{
${ }^{11}$ About the National Offender Management Service http://www.justice. gov.uk/about/noms

${ }^{12}$ Powers of Criminal Courts Act 2000 http://www.legislation.gov.uk/ ukpga/2000/6/section/8

${ }^{13}$ Children Act 2001 http://www.dcya.gov.ie/documents/YouthJustice/ a2401.pdf
}

Таким образом, можно сделать вывод, что бесплатные работы - этораспространенная мера уголовно-правового воздействия в современной Англии, применяемая в связи с широким кругом уголовных преступлений и являющаяся альтернативой лишению свободы, что позволяет говорить о снижении репрессивностипенитенциарной системы в Англии. Несмотря на введение системы исполнения наказаний альтернативных лишению свободытолько в 2000 - 2005 гг. ${ }^{14}$, эту систему можно охарактеризовать как тщательно отрегулированную, с высоким уровнем структурированности и разветвленности, что позволяет обеспечить качественное решение вопросов о мерах предупреждения рецидива и возмещения вреда потерпевшему.

Анализ норм уголовного и уголовно-исполнительного законодательства о назначении и исполнении бесплатных работ в рамках романо-германской правовой семьи (на примере Франции) позволяет выделить их существенные отличия от соответствующих норм англо-американского права.

Система права Франции, как и любой страны романо-германской правовой семьи, предполагает дихотомическое деление права на частное и публичное, материальное и процессуальное, что выражается в действии Уголовного кодекса Франции и Уголовно-процессуального кодекса Франции как самостоятельных нормативно-правовых актов. Факт наличия отраслевых кодексов подразумевает другую особенность - выделение отдельных отраслей права, как элементов системы романо-германского права. Третья особенность - приоритет закона над иными источниками права, что предполагает необходимость в первую очередь ссылаться на нормы закона для подтверждения аргументации при вынесении решений по уголовным делам.

Указанные особенности системы романо-германского права имеют значение для исследования практики назначения и исполнения альтернативных наказаний, связанных с трудовым воздействием на осужденного, в связи с тем, что специфика системы в целом отражается и в особенностях отдельных правовых институтов. В отличие от стран англо-американской правовой семьи во Франции «работы в интересах общества» (un travail d'intérêt general) являются самостоятельным законодательно закрепленным уголовным наказанием, значение которого не ограничивается рамками альтернативы лишению свободы.

\footnotetext{
${ }^{14}$ Criminal Justice Act 2003 http://sentencingcouncil.judiciary.gov.uk/ docs/web_new_sentences_guideline1.pdf
} 
DOI: 10.7256/1811-9018.2014.10.12952

При цитировании этой статьи сноска на dоі обязательна

\section{Право и политика $10(178) \cdot 2014$}

Работы в интересах общества могут применяться судом как самостоятельный вид уголовного наказания, также в качестве альтернативы лишению свободы, либо в качестве одного из условий условного осуждения лица, то есть сфера применения работ в интересах общества во Франции, по сравнению с Англией, расширена.

В соответствии со статьями 131-8 и 131-8-1 Уголовного кодекса, если преступление наказывается лишением свободы, суд имеет право заменить этот вид наказания на работы в общественных интересах размером от 20 до 210 часов, которые не могут стать основанием для получения прибыли юридическим лицом ни в частном, ни в публичном праве. Если преступление наказывается лишением свободы и восстановительно-ремонтными работами до 6 месяцев - действует аналогичное правило замены. Замена наказания осуществляется при соблюдении двух условий: уведомление и получение согласия осужденного, личное присутствие осужденного в зале судебного заседания. Следовательно, законодательное закрепление правил назначения работ в общественных интересах предусматривает дополнительную гарантию соблюдения прав и свобод человека, при этом замена лишения свободы работами в интересах общества является не обязанностью, а правом суда, реализуемым по собственной инициативе или по ходатайству осужденного.

Отбывание работ в общественных интересах происходит до полной отработки назначенных судом часов работ. Максимально допустимая длительность исполнения наказания составляет 18 месяцев. Время выполнения работ может быть приостановлено мотивированным приказом при наличии уважительных причин, к которым Уголовный кодекс Франции относит медицинские, семейные, профессиональные и социальные причины, не раскрывая понятий ${ }^{15}$. Время исполнения работ в интересах общества может быть приостановлено при нахождении осужденного под домашним арестом (вид уголовного наказания) с использованием электронного мониторинга. Назначение работ в интересах общества как самостоятельного уголовного наказания входит в компетенцию полицейских и исправительных трибуналов, также трибуналов по делам с участием несовершеннолетних ${ }^{16}$.

\footnotetext{
${ }^{15}$ УК Франции Code pénal http://www.legifrance.gouv.fr/affichCode. do;jsessionid=0DB32EF259C2F56294C051C8DB0A9B9D.tpdjo04v _3 ?idSectionTA $=$ LEGISCTA000006181727\&cidTexte $=$ LEGITEXT0 $00006070719 \&$ dateTexte $=20100907$

${ }^{16}$ УПК Франции Code de procedure penale de la France http://www. legifrance.gouv.fr/affichCode.do?cidTexte=LEGITEXT00000607115 $4 \&$ dateTexte $=20120724$
}

Полицейские трибуналы (le tribunal de police) - суды в составе единоличного судьи - выносят приговоры в связи с проступками 5 класса ${ }^{17}$, которые наказываются лишением свободы и штрафами в размере до 1,5 (3 при рецидиве) тысяч евро, также дела, связанные с таможенными вопросами. К таким проступкам могут относиться незаконная парковка, осквернение флага, причинение средней тяжести вреда здоровью. Полицейские трибуналы могут назначить работы в интересах общества на срок от 20 до 120 часов.

Исправительные трибуналы (le tribunal correctionnel) - коллегиальные суды, рассматривающие уголовные дела по более серьезным уголовным преступлениям, наказываемым штрафами до 4 тысяч евро или лишением свободы на срок от 2 месяцев до 10 лет (délit pénal) ${ }^{18}$, к числу которых УК Франции относит убийства, насильственные действия сексуального характера, кражи. Исправительные трибуналы могут назначить работы в интересах общества в пределах от 40 до 210 часов.

Особенность судопроизводства во Франции и других странах романо-германской правовой семьи составляет деятельность прокуратуры, как отдельной власти по надзору за соблюдением прав и свобод лиц, участвующих в деле. В ходе судебного заседания и в прениях прокурор имеет право подать представление о замене работ в интересах общества другим видом наказания или замене лишения свободы работами в интересах общества. При решении вопроса о назначении наказания в течение 10 дней после вступления приговора в силу прокурор имеет право обжаловать решение суда. При исполнении работ в интересах общества и несоблюдении осужденным установленных законодательством условий, прокурор может ходатайствовать в суде об изменении наказания осужденному.

Особенностью исполнения работ в интересах общества является добровольное участие юридических лиц частного права (les personnes morales de droit privé) в качестве посредников. УК Франции устанавливает возможность участия юридических лиц в исправлении осужденных путем привлечения их труду в указанных организациях. В соответствии со ст. 131-12 юридические лица частного права могут подавать заявления о включении их в реестр юридических лиц, взаимодействующих с судом в целях исполнения работ в интересах общества. При этом законодательство ограничивает

\footnotetext{
${ }^{17}$ Общественная опасность данных проступков выше, чем у классов 1-4.

${ }^{18}$ Категория уголовных правонарушений, близкая к категории преступлений по УК РФ средней тяжести и тяжким.
} 
права организаций, устанавливая строгий перечень документов, необходимых для регистрации организации в реестре, проверяя финансовый баланс и запрещая получение прибыли от бесплатного труда осужденных.

При исполнении наказания, связанного с трудовым воздействием, решается вопрос о дополнительном урегулировании прав осужденных трудовым законодательством, предусматривающим законные условия труда, обеспечиваются гарантии прав работника. Если в законодательстве Англии нет правовых положений, гарантирующих защиту прав осужденных как лиц, выполняющих бесплатную работу или отсылающих правоприменителя к трудовому законодательству, то во Франции законодательно закреплены положения о труде осужденных, и есть прямые ссылки на нормы трудового права. В соответствии со статьей 131-23 УК Франции при исполнении работ в интересах общества должны быть соблюдены все законы и правила, касающиеся работы в ночное время, гигиены, безопасности труда, отдельных положений о труде женщин и несовершеннолетних лиц. Таким образом, государство не выделяет осужденных в качестве отдельной категории граждан, не ущемляет права этих лиц, не нарушает норм международного публичного права. Выполнение работ может осуществляться одновременно с выполнением трудовых функций по основному месту оплачиваемой работы. Государство несет ответственность за вред, причиненный осужденному в процессе отбывания наказания, если этот вред наступил не по вине самого лица. Иск об ответственности подается в суд для рассмотрения и принятия решения о присуждении денежной компенсации.

УК Франции по общему правилу не устанавливает обязательных мест отбывания работ. Статья 131-22 предусматривает исключение из этого правила, предписывая лицам, осужденным за преступление, связанное с нарушением правил дорожного движения работу в специализированном ведомстве по регистрации случаев дорожно-транспортных происшествий. Работы отбываются по месту жительства лица.

Видами деятельности, выполняемыми в рамках работ в общественных интересах, могут быть озеленение жилых кварталов, устранение последствий актов вандализма и т.д. Исполнением уголовных наказаний занимается пенитенциарная служба, включающая службу пробации (Le Service pénitentiaire d'insertion et de probation - SPIP) ${ }^{19}$. Особенностей в характере работ и способе их выполнения во Франции, по сравнению с Англией, нет.

\footnotetext{
${ }^{19}$ Le Travail d'Intérêt Général. Une alternative à l'incarcération. Direction de l'administration pénitentiaire http://www.vie-publique. fr/documents-vp/tig.pdf
}

В соответствии со ст.132-40, 132-41, 132-42 УК Франции применение условного осуждения с дополнительным выполнением работ в интересах общества с испытательным сроком (le sursis avec mise à l'épreuve ${ }^{20}$ ) допускается в случаях установления особых обязанностей осужденному, позволяющих осуществлять контроль за поведением лица и достичь целей наказания без лишения свободы. При этом испытательный срок не может быть менее 12 месяцев и более 3 лет, при рецидиве может быть продлен до 7 лет. Условное осуждение с испытательным сроком возможно при назначении лицу наказания в виде лишения свободы до 5 лет, а в случае рецидива - до 10 лет. Если ранее лицу дважды назначалось условное осуждение с испытательным сроком, и было совершено новое преступление - третье назначение аналогичной меры наказания запрещено. В соответствии с УК Франции выполнение работ в интересах общества с испытательным сроком не может быть назначено при совершении осужденным таких деяний как: нападения, преступления с применением насилия, преступления против половой неприкосновенности и половой свободы, а также квалифицированные составы преступлений ${ }^{21}$. При отбывании условного осуждения с испытательным сроком применяются правила, аналогичные правилам отбывания работ в интересах общества.

Во Франции, как и в странах англо-американской правовой семьи, допускается назначение работ в интересах общества несовершеннолетним лицам. Специализированные суды - трибуналы по делам с участием несовершеннолетних (le tribunal pour enfants) - имеют право назначать работы в интересах общества осужденным в возрасте 16-18 лет ${ }^{22}$ за уголовные преступления (delits), наказываемые лишением свободы. Ответственной за исполнение наказаний является организация юридической защиты несовершеннолетних (La direction de la protection judiciaire de la jeunesse - DPJJ), подчиняющаяся Министерству юстиции ${ }^{23}$.

\footnotetext{
${ }^{20}$ УК Франции Code pénal http://www.legifrance.gouv.fr/affichCode. do;jsessionid=0DB32EF259C2F56294C051C8DB0A9B9D.tpdjo04v 3? idSectionTA $=$ LEGISCTA000006181727\&cidTexte $=$ LEGITEXT0 00006070719\&dateTexte $=20100907$

${ }^{21}$ УК Франции Code pénal http://www.legifrance.gouv.fr/affichCode. do;jsessionid=0DB32EF259C2F56294C051C8DB0A9B9D.tpdjo04v 3 ? idSectionTA $=$ LEGISCTA000006181727\&cidTexte $=$ LEGITEXT0 00006070719\&dateTexte $=20100907$

${ }^{22}$ Le Travail d'Intérêt Général. Une alternative à l'incarcération. Direction de l'administration pénitentiaire. http://www.vie-publique.fr/ documents-vp/tig.pdf

${ }^{23}$ Le travail d'intérêt general http://www.justice.gouv.fr/justice-des-mineurs-10042/le-travaildinteret-general-22236.html
} 
DOI: 10.7256/1811-9018.2014.10.12952

При цитировании этой статьи сноска на dоі обязательна

\section{Право и политика $10(178) \cdot 2014$}

Привлечение лиц пониженной возрастной категории к работам в интересах общества является частью образовательного процесса и процесса социальной интеграции личности. Так, например, несовершеннолетние могут участвовать в акциях Красного Креста, работать в бесплатных столовых, озеленять улицы.

Пенитенциарная система каждой из рассмотренных стран имеет свои особенности, вызванные государственным устройством, политикой государства, принадлежностью к разным правовым семьям, но наблюдается тенденция к глобализации законодательства, заимствованию многих правовых институтов.

Близкие по содержанию меры могут быть восприняты одинаково в странах разных правовых систем. По содержанию и видам осуществляемых работ меры уголовно-правового воздействия в виде бесплатных работ (Англия) и работы в интересах общества (Франция) идентичны. Возможность назначения альтернативных наказаний, связанных с трудовым воздействием, несовершеннолетним предусмотрена и законодательством Англии, и законодательством Франции.

Вместе с тем, обнаруживаются существенные отличия при назначении и исполнении альтернативных наказаний, связанных с трудовым воздействием, что обусловлено разным пониманием их природы. Во Франции работы в интересах общества рассматриваются в качестве самостоятельного вида наказания, альтернативного лишению свободы, в то время как в Англии применение бесплатных работвозможно лишь как одно из условий специального приговора - в интересах общества. Во Франции установлен предельный срок отбывания работ в общественных интересах продолжительностью 18 месяцев. Система назначения альтернативных наказаний, связанных с трудовым воздействием, во Франции предусматривает разветвленную систему судов, обладающих правом назначения работ в интересах общества (исправительные и полицейские трибуналы, трибуналы по делам несовершеннолетних). В Англии назначить приговор в интересах общества с указанием объема бесплатных работ уполномочен любой судья. Во Франции приоритетно включение негосударственных организаций в качестве посредников при отбывании осужденными альтернативных видов наказаний. В Англии исполнение наказаний, связанных с трудовым воздействием, подчинено разветвленной системегосударственных служб, закрепляющих за каждым служащим отдельных осужденных. Во Франции исполнение приговора осуществляется без подписания дополнительных актов, в Англии для исполнения наказания требуется заключение контракта с составлением индивидуального плана выполнения бесплатных работ.

Таким образом, обусловленные едиными тенденциями к глобализации уголовно - правового регулирования, ее либерализацией и гуманизацией уголовно - правовой политики, уголовные наказания, альтернативные лишению свободы, востребованы в разных правовых системах современного мира. Этот опыт может быть полезен для оптимизации системы наказаний в России.

\section{Библиография:}

1. Конвенция о рабстве 1926 г. http://www.un.org/ru/documents/decl_conv/conventions/convention_slavery.shtml

2. Criminal Justice Act $2003 \mathrm{http}: / /$ sentencingcouncil.judiciary.gov.uk/docs/web_new_sentences_guideline1.pdf

3. Joan Petersilla Probation in the USA http://www.appa-net.org/eweb/Resources/PPPSW_2013/docs/sp98pers30.pdf

4. Code penal de la France http://www.legifrance.gouv.fr/affichCode.do;jsessionid=0DB32EF259C2F56294C051C8DB0A9B9D.tp djo04v_3?idSectionTA=LEGISCTA000006181727\&cidTexte=LEGITEXT000006070719\&dateTexte=20100907

5. About the National Offender Management Service http://www.justice.gov.uk/about/noms

6. Powers of Criminal Courts (Sentencing) Act 2000 http://www.legislation.gov.uk/ukpga/2000/6/section/8

7. Children Act http://www.dcya.gov.ie/documents/YouthJustice/a2401.pdf

8. Criminal Justice and Immigration Act 2008 http://www.legislation.gov.uk/ukpga/2008/4/contents

9. Referral Order Guidance http://www.justice.gov.uk/downloads/youth-justice/referral-orders/referral-order-guidance.pdf

10. Code de procédure pénale de la France http://www.legifrance.gouv.fr/affichCode.do?cidTexte=LEGITEXT000006071154\&dateTexte=20120724

11. Le Travail d'Intérêt Général. Une alternative à l'incarcération. Direction de l'administration pénitentiaire http://www.vie-publique. fr/documents-vp/tig.pdf

12. Le travail d'intérêt general http://www.justice.gouv.fr/justice-des-mineurs-10042/le-travail-dinteret-general-22236.html

13. Дворянсков И. В. Эффективность альтернативных наказаний. - М., 2005.

14. Дворянсков И. В., Сергеева В.В., Баталин Д. Е. Применение альтернативных видов наказания в Западной Европе, США и России. Центр содействия реформе уголовного правосудия. - М., 2003.

15. Зайченко В. А. Альтернативные лишению свободы наказания как средство оптимизации системы уголовных наказаний в США: Автореф. дис... канд. юрид. наук. Самара, 2005.

16. Урсул А.Д., Урсул Т.А. Глобализация в перспективе устойчивого будущего // NB: Вопросы права и политики. - 2013. 5. - C. 1-63. DOI: 10.7256/2305-9699.2013.5.794. URL: http://www.e-notabene.ru/lr/article_794.html 
17. Комахин Б.Н.. Дисциплинарная ответственность служащих за коррупцию // Полицейская деятельность. - 2013. - № 5. - C. 104-107. DOI: 10.7256/2222-1964.2013.5.10246

18. Савченко Д.А. Правовая защита безопасности государства по уголовному законодательству средневекового Китая // Журнал зарубежного законодательства и сравнительного правоведения. - 2013. - 5. - С. 891-897.

19. Сиромаха О.В. О психологической неэффективности наказания как воспитательного средства // NB: Психология и психотехника. - 2013. - № 8. - C.80-101. DOI: 10.7256/2306-0425.2013.8.10636. URL: http://e-notabene.ru/psp/ article_10636.html

20. Никулин В.В. Правосудие и политика: соотношение политики и права в советской системе наказаний // NB: Исторические исследования. - 2013. - № 5. - C.1-59. DOI: 10.7256/2306-420X.2013.5.747. URL: http://e-notabene.ru/hr/article_747.html

21. Кухарук B.B. Отсрочка отбывания наказания больным наркоманией: вопросы теории и реализации // NB: Вопросы права и политики. - 2013. - № 1. - C.148-165. DOI: 10.7256/2305-9699.2013.1.366. URL: http://e-notabene.ru/lr/article_366.html

22. Афанасенко Я.А. Вина: между наказанием и прощением // NB: Философские исследования. - 2012. - № 4. - C.129-178. DOI: 10.7256/2306-0174.2012.4.245. URL: http:/e-notabene.ru/fr/article_245.html

23. Гришковец А.А.. Дисквалификация государственных гражданских служащих // Административное и муниципальное право. - 2013. - № 12. - С. 104-107. DOI: 10.7256/1999-2807.2013.12.10174

24. Кареева-Попелковская К.А.. Меры административного пресечения и проблемы их реализации в деятельности полиции // Полицейская деятельность. - 2013. - № 6. - С. 104-107. DOI: 10.7256/2222-1964.2013.6.10597

25. Афонькин Г.П., Додонов О.Е.. К вопросу о предоставлении отсрочки отбывания наказания больным наркоманией // Полицейская деятельность. - 2013. - № 5. - С. 104-107. DOI: 10.7256/2222-1964.2013.5.10038

26. Обыденов В.В.. К вопросу о содержание обстоятельств, смягчающих административную ответствен-ность и их соотношение с обстоятельствами связанными с освобождением от административной от-ветственности // Административное и муниципальное право. - 2013. - № 10. - С. 104-107. DOI: 10.7256/1999-2807.2013.10.9717

27. Обыденов В.В.. Обстоятельства смягчающие административную ответственность в юрисдикционной деятельности полиции // Полицейская деятельность. - 2013. - № 4. - C. 104-107. DOI: 10.7256/2222-1964.2013.4.9582

28. Паньшин Д.Л., Дресвянникова Е.А.. Вопросы вступления в законную силу постановлений по делам об административных правонарушениях в области дорожного движения // Административное и муниципальное право. - 2013. - № 8. - С. 104-107. DOI: 10.7256/1999-2807.2013.8.9099

29. И. В. Шильникова. Наказание как элемент системы стимулирования труда рабочих-текстильщиков в Советской России (1918-1929): опыт микроанализа // Исторический журнал: научные исследования. - 2013. - № 4. - C. 104-107. DOI: $10.7256 / 2222-1972.2013 .4 .877$

\section{References (transliterated):}

1. Joan Petersilla Probation in the USA http://www.appa-net.org/eweb/Resources/PPPSW_2013/docs/sp98pers30.pdf

2. Dvoryanskov I. V. Effektivnost' al'ternativnykh nakazanii. - M., 2005.

3. Dvoryanskov I. V., Sergeeva V.V., Batalin D. E. Primenenie al'ternativnykh vidov nakazaniya v Zapadnoi Evrope, SShA i Rossii. Tsentr sodeistviya reforme ugolovnogo pravosudiya. - M., 2003.

4. Zaichenko V. A. Al'ternativnye lisheniyu svobody nakazaniya kak sredstvo optimizatsii sistemy ugolovnykh nakazanii v SShA: Avtoref. dis... kand. yurid. nauk. Samara, 2005.

5. Ursul A.D., Ursul T.A. Globalizatsiya v perspektive ustoichivogo budushchego // NB: Voprosy prava i politiki. - 2013. - 5. - C. 1-63. DOI: 10.7256/2305-9699.2013.5.794. URL: http://www.e-notabene.ru/lr/article_794.html

6. Komakhin B.N.. Distsiplinarnaya otvetstvennost' sluzhashchikh za korruptsiyu // Politseiskaya deyatel'nost'. - 2013. - S. 104-107. DOI: 10.7256/2222-1964.2013.5.10246

7. Savchenko D.A. Pravovaya zashchita bezopasnosti gosudarstva po ugolovnomu zakonodatel'stvu srednevekovogo Kitaya // Zhurnal zarubezhnogo zakonodatel'stva i sravnitel'nogo pravovedeniya. - 2013. - 5. - C. 891-897.

8. Siromakha O.V. O psikhologicheskoi neeffektivnosti nakazaniya kak vospitatel'nogo sredstva // NB: Psikhologiya i psikhotekhnika. - 2013. - № 8. - S.80-101. DOI: 10.7256/2306-0425.2013.8.10636. URL: http://e-notabene.ru/psp/article_10636.html

9. Nikulin V.V. Pravosudie i politika: sootnoshenie politiki i prava v sovetskoi sisteme nakazanii // NB: Istoricheskie issledovaniya. - 2013. - № 5. - S.1-59. DOI: 10.7256/2306-420X.2013.5.747. URL: http://e-notabene.ru/hr/article 747.html

10. Kukharuk V.V. Otsrochka otbyvaniya nakazaniya bol'nym narkomaniei: voprosy teorii i realizatsii // NB: Voprosy prava i politiki. - 2013. - № 1. - S.148-165. DOI: 10.7256/2305-9699.2013.1.366. URL: http://e-notabene.ru/lr/article_366.html

11. Afanasenko Ya.A. Vina: mezhdu nakazaniem i proshcheniem // NB: Filosofskie issledovaniya. - 2012. - № 4. - S.129-178. DOI: 10.7256/2306-0174.2012.4.245. URL: http://e-notabene.ru/fr/article_245.html

12. Grishkovets A.A.. Diskvalifikatsiya gosudarstvennykh grazhdanskikh sluzhashchikh // Administrativnoe i munitsipal'noe pravo. - 2013. - № 12. - S. 104-107. DOI: 10.7256/1999-2807.2013.12.10174

13. Kareeva-Popelkovskaya K.A.. Mery administrativnogo presecheniya i problemy ikh realizatsii v deyatel'nosti politsii // Politseiskaya deyatel'nost'. - 2013. - № 6. - S. 104-107. DOI: 10.7256/2222-1964.2013.6.10597

14. Afon'kin G.P., Dodonov O.E.. K voprosu o predostavlenii otsrochki otbyvaniya nakazaniya bol'nym narkomaniei // Politseiskaya deyatel'nost'. - 2013. - № 5. - S. 104-107. DOI: 10.7256/2222-1964.2013.5.10038 
DOI: 10.7256/1811-9018.2014.10.12952

При цитировании этой статьи сноска на dоі обязательна

\section{Право и политика $10(178) \cdot 2014$}

15. Obydenov V.V.. K voprosu o soderzhanie obstoyatel'stv, smyagchayushchikh administrativnuyu otvetstven-nost' i ikh sootnoshenie s obstoyatel'stvami svyazannymi s osvobozhdeniem ot administrativnoi ot-vetstvennosti // Administrativnoe i munitsipal'noe pravo. - 2013. - № 10. - S. 104-107. DOI: 10.7256/1999-2807.2013.10.9717

16. Obydenov V.V.. Obstoyatel'stva smyagchayushchie administrativnuyu otvetstvennost' v yurisdiktsionnoi deyatel'nosti politsii // Politseiskaya deyatel'nost'. - 2013. - № 4. - S. 104-107. DOI: 10.7256/2222-1964.2013.4.9582

17. Pan'shin D.L., Dresvyannikova E.A.. Voprosy vstupleniya v zakonnuyu silu postanovlenii po delam ob administrativnykh pravonarusheniyakh v oblasti dorozhnogo dvizheniya // Administrativnoe i munitsipal'noe pravo. - 2013. - № 8. - S. 104-107. DOI: 10.7256/1999-2807.2013.8.9099

18. I. V. Shil'nikova. Nakazanie kak element sistemy stimulirovaniya truda rabochikh-tekstil'shchikov v Sovetskoi Rossii (1918-1929): opyt mikroanaliza // Istoricheskii zhurnal: nauchnye issledovaniya. - 2013. - № 4. - S. 104-107. DOI: 10.7256/2222-1972.2013.4.877 